\title{
Poem D
}

Auschwitz; I heard that you're in style.

Nice men talk about you with respect.

A little more, and you will be so swaddled

In paper leaves

That you will crunch like driven snow.

Everything will be whitest white, but for the printed letters

Sieg-heiling goose-stepping battalions.

\section{Poem E}

I saw them, three baby-faced Germans

Nestling in a Cafe in Notre Dame,

So fresh upon the morning

Three baby-faced Germans,

Their hair the smell of the field,

Their faces unshod.

The rain came down on town and the Seine,

Flushing paved streets

Stale spit and yesterday's headlines

Down gutters,

Beating on Notre Dame and Seine,

Dripping down lashes of passers-by

Who glided like weeping columns

In windowpanes on squeaking hinges,

Facing them, the baby-faced Germans. 